Egypt. J. of Nutrition and Health Vol. 15 No. 1 January (2020)

\title{
The comparative study on daily Talbinah intake to ameliorative levels of protein, iron and zinc for adult girls
}

\author{
Ola Ibrahim El-Desoky Ali \\ Nutrition and Food Science Department, Faculty of Home Economics, Al-Azhar \\ University, Tanta, Egypt.
}

\begin{abstract}
The study attributes to confirm the role of talbinah to adjust protein and mineral level as a nutritional problem of adult girls. Chemical composition of barley grains was examined. Nutritional value of talbinah was calculated. Body mass index as weight marker was calculated and nutrient percentages to Dietary Reference intakes (DRIs). Hemoglobin $(\mathrm{Hb})$, serum iron, ferritin, total iron binding capacity (TIBC), serum zinc and albumin were tested as biochemical blood data. The results of barley grains chemical composition recorded mild content of protein, fiber, calories and minerals. Calculated nutritional value of talbinah revealed high content of nutrients. Body mass index percent were high percent of ideal weight followed by overweight and low percent in obesity and underweight girls. On daily intake of talbinah the percent of macronutrients and vitamins were increased compared to DRIs in all groups. But minerals percent recorded high decrease in all groups. All blood results of $\mathrm{Hb}$, serum iron, ferritin, TIBC, zinc and albumin levels were improved by girls taking 2 cups then 1 cup of talbinah. So, this results can confirm that use of the talbinah improved adult girl's nutritional status.
\end{abstract}

Key words: barley, milk, Hemoglobin, iron, ferritin, TIBC.

\section{Introduction}

Talbinah is made of barley flour, which is a great nutritious breakfast food and filling. Talbinah is a barley syrup cooked with milk and sweetened by honey (Badrasawi et al., 2013). It was popular as traditional medicine and great nutritious breakfast food and filling (Abd EI-Rahman, 2001).

Whole barley grains are rich in the soluble fibers as $\beta$-glucans and pectin which are useful in reduction of the glycaemic index (Gl) and insulinaemic response. The effect of barley consumption was amelioration of the liver cells of diabetic rat (Khalaf and Mohamed, 2008).

Buffalo milk is not consumed everywhere in the world. But it has many health benefits such as promotes growth, builds strong bones, stimulates circulation, protects the heart and lowers the blood pressure. Buffalo milk contains a good amount of vitamins A and B which are key to the functioning of our immune system and protection of the body. Zinc and certain other trace minerals have variety of antioxidants which act as immune system boosters (Elagamy, 2000).

Measuring serum ferritin can detect iron deficiency and overload. Since iron deficiency is present before the onset of anemia, thus, detection of iron depletion is important for the treatment of nutritional anemia (Krause and Stolc, 1979). Historically, the clinical estimation of iron stores has relied on the determination of serum iron, total iron-binding capacity (TIBC) and transferrin. Recent 


\section{Ola Ibrahim El-Desoky Ali}

literature revealed to a more sensitive, specific and reliable measurement of ferritin to detect an early stage of iron deficiency (Bates, 1980).

Pervious researches clarified the importance of albumin in maintaining the fluid balance in the body, helping to prevent the blood vessels from excessive filtrate. Also, albumin has a role in repairing tissue and helping the body to grow during transporting vital hormones and nutrients (Shishira et al., 2016).

\section{Objective of the study}

This study was carried out to investigate the role of talbinah to adjust protein and mineral level to combat a nutritional problems of adult girls.

\section{Materials and Methods}

\section{Materials}

Barley grains (Giza 126), fresh buffalo milk and honey were purchased from local markets and ground by mechanical apparatus. Talbinah prepared freshly and take one or two cups $(200 \mathrm{ml} /$ one cup) once and twice day .

\section{Methods}

Moisture, protein, crude fibers and ash contents of barley were determined according to the methods described in the (A.O.A.C., 1997). Crude fat content was determined as the ether extract (A.O.C.S., 1994). Total carbohydrate was calculated by difference according to Pellet and Sossy (1970).The caloric value was calculated using values of 4 k.cal. $/ \mathrm{g}$ of protein, 4 k.cal. / g of carbohydrates and 9 k.cal./g of fat according to Livesy (1995). To extract $\mathrm{Na}, \mathrm{K}, \mathrm{Mg}, \mathrm{Ca}, \mathrm{Zn}$ and $\mathrm{Fe}$ samples were dried, ashed then the ash was dissolved in hydrochloric acid (Jackson, 1973). Sodium and potassium were determined by the flame photometric procedure (Corning instrument model 400) (Chapman and Pratt, 1961).

The study was designed to find the effect of two different daily intake of talbinah on nutritional status, iron status, zinc and protein. Girls were chosen at the reproductive stage 19-23 years old, which is very important period in women life. Girls were chosen before the start of the study and classified into three groups, 20 girls each, one as control, talbinah 1 (take one cup /day) and talbinah 2 (take two cups /day). It was either taken as breakfast or between meals on an empty stomach. The study performed between October to December 2017 for 12 weeks in Gharbia governorate, Egypt. The nutritional data were collected in questionnaire form by personal contact and interview of 24 hour recall and data were presented as a percent of daily intake of nutrients (Wardley, 1997) compared to Dietary Reference Intakes DRIs (1997). Body Mass Index (BMI): was calculated by equation as weight in $\mathrm{kg} / \mathrm{height}$ in $\mathrm{m}^{2}$ (Park and Park, 2010); and (WHO, 2004) before starting the study to classified girls.

\section{Preparing Talbinah:}

The ingredients: Two tablespoons of ground barley $(20 \mathrm{~g}), 150 \mathrm{ml}$ of full cream liquid buffalo milk, $25 \mathrm{ml}$ of water and a teaspoon of honey.

Method of preparation: the investigator put the amount of water in a pot, then added the barley, and mix the ingredients with the hand until the mixture became homogenous without forming blocks of flour. The pot was placed in a water bath and raised it over medium heat, stirring continuously until the mixture became puffy. Milk and honey were added to the mixture, and continuous stirring until the ingredients became homogenous. The talbinah was taken off the fire and left sometime before 


\section{Egypt. J. of Nutrition and Health Vol. 15 No. 1 January (2020)}

preparing the cups. Blood samples were divided into two tubes. The first test tube containing Drabkins solution were prepared to determine blood hemoglobin $(\mathrm{Hb})$ according to Betk and Savelsberg (1950). The other blood sample was taken in clean dry centrifuge tubes, left to clot at room temperature, and centrifuged for 10 minutes at $3000 \mathrm{rpm}$ to separate the serum and kept frozen till analysis. Clinical examination was done at the same time for checking serum iron and total iron binding capacity (TIBC) were measured by colorimetric method by Van et al., (1995). Serum ferritin was determined according to Forman and Parker (1980). Analysis of zinc was determined by using flame atomic absorption spectrometry (Thermo Jarrel Ash, Germany) according to the method of Kirgbright (1980).

Data was statistically analyzed using SPSS 20.0 software package and presented in tables as percentage and means \pm standard deviation (S.D.). Paired $t$ test was used $p$ value $\leq 0.05$ was the level of significance according to Kalton, (1967).

\section{Results and Discussion}

Chemical composition of barley grains (Giza 126): Table (1) recorded the chemical composition percentage of barley grains powder and the mineral contents in dry bases. From the obtained data results showed that $11.9 \%$ of moisture, $8.8 \%$ protein, $2.6 \%$ fat, $3.8 \%$ crude fiber, $81.85 \%$ carbohydrate, $2.85 \%$ ash and $386.74 \mathrm{kcal}$ energy as macronutrients and caloric value. While, micronutrients recorded $8.41 \mathrm{mg}$ iron, $5.67 \mathrm{mg}$ zinc, $1.8 \mathrm{mg}$ manganese, $47.25 \mathrm{mg}$ sodium and $3.2 \mathrm{mg}$ potassium/ $100 \mathrm{~g}$ of barley grain powder.

Table (1)

Macronutrients (\%) and minerals contents (mg/ 100g) in dry barley grains (Giza 126)

\begin{tabular}{c|c|c|c|c|c|c|c|c|c|c|c}
\hline Moisture\% & $\begin{array}{c}\text { Crude } \\
\text { protein\% }\end{array}$ & $\begin{array}{c}\text { Crude } \\
\text { fat\% }\end{array}$ & $\begin{array}{c}\text { Crude } \\
\text { fiber\% }\end{array}$ & Ash \% & Carbohydrates \% & $\begin{array}{c}\text { Caloric value } \\
\text { (Kcal) }\end{array}$ & Fe mg & Zn mg & Mg mg & Na mg & K mg \\
\hline 11.90 & 8.8 & 2.7 & 3.8 & 2.85 & 81.85 & 386.74 & 8.41 & 5.67 & 1.8 & 47.25 & 3.2 \\
\hline
\end{tabular}

Table (2) contains the nutritional value of one and two cups of talbinah according to the food composition table of the National Nutrition Institute (NNI) in Egypt (2006). For the various ingredients of talbinah content of barley flour, buffalo milk and honey had high nutritional value on taking 2 cups. This confirm that talbinah can fulfill the needs of human body especially in the early stages of life and the stages associated with physical activity.

Table (2)

Nutritional value of talbinah according to the National Nutrition Institute in Egypt (2006)*

\begin{tabular}{|c|c|c|c|c|c|c|c|c|c|c|c|c|c|c|}
\hline Talbinah & Protein g & Fat $\mathrm{g}$ & $\mathrm{CHO} \mathrm{g}$ & $\begin{array}{c}\text { Calories } \\
\text { (Kcal) }\end{array}$ & $\vee A \mu g$ & V B1 mg & V B $2 \mathrm{mg}$ & $\vee C \mathrm{mg}$ & Ca mg & Fe mg & $\mathrm{Zn} \mathrm{mg}$ & $\mathrm{Mg} \mathrm{mg}$ & $\mathrm{Na} \mathrm{mg}$ & $\mathrm{K} \mathrm{mg}$ \\
\hline $\begin{array}{c}1 \text { cup } \\
\text { (200ml) }\end{array}$ & 7.7 & 12.5 & 27.8 & 254.5 & 518.6 & 0.6 & 2.41 & 4.66 & 1461.9 & 4.07 & 6.7 & 122.8 & 523.4 & 1428.2 \\
\hline $\begin{array}{l}2 \text { cups } \\
(400 \mathrm{ml})\end{array}$ & 15.4 & 25.1 & 55.7 & 510.3 & 1037.2 & 1.2 & 4.81 & 9.33 & 2923.8 & 8.15 & 13.4 & 245.5 & 1046.8 & 2856.5 \\
\hline
\end{tabular}

${ }^{\star}$ The figure in the table was done using NNI table for the ingredients

Many researchers confirmed its use as a remedy recipes (Bassem, 2016). Talbinah is an Arabic word was named after being liked for its milk content (Abdel-Hassib,2007). The past decade has seen a keen interest in nutraceuticals or functional foods (Hosseinzadeh et al., 2015). Talbinah is a high-value nutritional syrup cooked with milk and sweetened by honey that is included under functional foods. The present study was in agreement with the study of barley varieties namely: Giza126 and Giza 130 by barley flour and germinated barley. The data found that protein content of 


\section{Ola Ibrahim El-Desoky Ali}

raw studied and processing treatments ranged from $8.75-18.34 \mathrm{~g} / 100 \mathrm{~g}$ on dry weight basis and slight decrease in crude fat content (Kamal et al., 2013).

Many researchers achieved that talbinah has the potential to diminish depression and enhance mood among the subjects. Ingestion of functional foods such as talbinah may improve mental health to elderly people (Badrasawi et al., 2013). Several plants such as barley and honey of the latest findings linking the bioactivity with the pathogenesis of diabetes and insulin secretion in diabetes mellitus patients (Bassem, 2016). In addition, talbinah is potentially safe for sedation as the content of neurotransmitters increased after daily oral administration of talbinah (barley water). Also, talbinah increased the plasma levels of testosterone and active spermatogenesis by rise of number of mature sperms. Hence, talbinah had beneficial effects on reproductive activity of male (Bawazir, 2010). Recent studies have confirmed that talbinah have ameliorating effect on pituitary-gonadal-adrenal disorders as well as the oxidative stress by hypothyroidism in adult female rats. So, talbinah acted on multi ways for protecting the physiological functions against hypothyroid adverse effect (Abd Rabo et al., 2018).

Barley is an ancient cereal grain, which has evolved from a largely food's grain to feed and malting grain Kumari and Kotecha (2015). Diets rich in whole grains have decreased the risk of many chronic diseases such as type II diabetes, coronary heart disease and certain cancers Cho et al., (2013). The beneficial effect of barley grains has often been attributed to their functional or bioactive components content. According to the results obtained by Hashemi (2015) barley is rich in many dietary fiber's tend to have health promoting components such as, minerals, phytochemicals and antioxidants. Our results agreed with Lahouar et al., (2017) who found that barely grains consumption can significantly improve the health of the population due to its high nutritional value and high content of bioactive compounds.

Buffaloes are the second largest milk source in the world after cows. It has a higher total solids content compared with cow milk (Sarfraz, 2013). Many researchers achieved that milk is a richer source of fat, whey protein, casein, lactose and minerals, it is good source of vitamins A and D but is deficient in vitamin $\mathrm{C}$ compared to cow's milk. So, it can be considered more nutritious for humans Khedkar and Deosarkar (2016).

All nutritional studies have gathered that honey is considered one of nature's valuable functional and medicinal foods. Honey have a complex mixture of sugars, especially fructose and glucose are the main constituents. Honey induced an increase in serum antioxidant capacity with honey consumption which possess novel antioxidant and antimicrobial properties. Natural honey lowered plasma glucose, $\mathrm{C}$ reactive protein, homocysteine, and blood lipids in healthy, diabetic, and hyperlipidaemic subjects. So as to, a recent clinical trial has shown that honey has been used as an alternative treatment for nearly 11 years for a volunteer patient with coronary heart disease, high blood pressure and type 2 diabetes who discontinued all traditional medicines (Bawazir., 2010). Given all these health benefits, honey was used as a natural sweetener for talbinah and raise its nutritional value.

Table (3) illustrated the calculated data of body mass index through the equation of dividing the weight $(\mathrm{kg})$ on the length in square meters and girls are classified before taking talbinah as percentage according to BMI classification. The percent demonstrated high percent $75 \%$ of control group have ideal weight and $25 \%$ were found in over weight range. Talbinah 1 group recorded middle percent $12.5 \%$ in underweight and obesity followed by high percent in ideal weight $50 \%$ followed by 


\section{Egypt. J. of Nutrition and Health Vol. 15 No. 1 January (2020)}

25\% over weight. Talbinah 2 group showed high percent of girls found in ideal weight followed by $57 \%$ and $43 \%$ in overweight.

Table (3)

Percent of girls group according to their Body Mass Index before taking talbinah

\begin{tabular}{l|c|c|c|c|c}
\hline Groups & $\mathrm{N}$ & Underweight & Ideal weight & Overweight & Obesity \\
\hline Control & $(20)$ & 0 & 75 & 25 & 0 \\
\hline Talbinah 1 & $(20)$ & 12.5 & 50 & 25 & 12.5 \\
\hline Talbinah 2 & $(20)$ & 0 & 57 & 43 & 0 \\
\hline
\end{tabular}

Talbinah 1 (had one cup of Talbinah /day), Talbinah 2 (had two cups of Talbinah /day), Underweight < 18.5, Ideal 18.5-24.9, Overweight 25-29.9 and Obesity 30-40

Body mass index (BMI) is a simple, inexpensive, and easy surrogate measure of body fat. In contrast to other methods, BMl relies merely on height and weight and with access to the proper equipment. Survey studies have shown that BMI levels correlate with body fat and with future health risks. So, BMI is an appropriate measure for screening for obesity and its health risks Centers for Disease Control and Prevention (CDCP) (2009 a). Hence, the scale of body mass index was taken to identify the health level of the girls under study and to be able to divide the groups according to their health status.

In table (4) data showed percentage of daily intake of nutrients as compared to DRIs for adult girls before taking talbinah. The intake of macronutrients as proteins recorded high percent beyond the established percentages in control, talbinah 1 and talbinah 2 groups. While, fats percent increase in control and talbinah 1 groups. Carbohydrate intake recorded high percent in control and talbinah 1 groups. The control group found as high percentages of energy followed by talbinah 1 group. About micronutrients all groups recorded high percent in vitamin $A, B_{1}, B_{2}$ and $C$. Minerals recorded very dangerous low percent in all groups especial in talbinah 1 groups.

Table (4)

Daily intake Percentage of nutrients consumed as compared to DRls before taking talbinah

\begin{tabular}{l|c|c|c|c|c|c|c|c|c|c|c|c}
\hline Groups & Protein (\%) & $\begin{array}{c}\text { Fats } \\
(\%)\end{array}$ & $\begin{array}{c}\text { CHO } \\
(\%)\end{array}$ & $\begin{array}{c}\text { Energy } \\
(\%)\end{array}$ & $\begin{array}{c}\text { Vit. A } \\
(\%)\end{array}$ & $\begin{array}{c}\text { Vit. B } \\
(\%)\end{array}$ & $\begin{array}{c}\text { Vit. B } \\
(\%)\end{array}$ & $\begin{array}{c}\text { Vit. C } \\
(\%)\end{array}$ & $\begin{array}{c}\text { Calcium } \\
(\%)\end{array}$ & $\begin{array}{c}\text { Iron } \\
(\%)\end{array}$ & $\begin{array}{c}\text { Zinc } \\
(\%)\end{array}$ & $\begin{array}{c}\text { Phosphorus } \\
(\%)\end{array}$ \\
\hline Control & 144.6 & 143.3 & 148.6 & 148.7 & 165.7 & 182.6 & 219.5 & 167.5 & 96.7 & 90.6 & 82.7 & 96.9 \\
\hline Talbinah 1 & 154.4 & 85.7 & 147.3 & 100 & 258.9 & 109.9 & 328.9 & 274.7 & 86.8 & 85.2 & 79.5 & 94.4 \\
\hline
\end{tabular}

During a 24-hour recall we reported all foods and beverages consumed over the preceding 24 hours. It started with the first thing eaten in the morning until the last food item consumed before sleep to the next morning. So, the method assessed the actual intake of individuals. (Food and Agriculture Organization of the United Nations Rome 2018). Hence the results of our study showed the importance of using this scale to detect the sharp decline in the level of mineral salts that may cause many diseases of malnutrition among these girls.

Table (5) illustrated data of hemoglobin $(\mathrm{Hb})$ levels after and before experimental period. Control group showed non-significant increase $(0.783 \mathrm{p} \leq 0.05)$. All talbinah groups recorded high significant values between after and before experimental period $(0.021$ and 0.000 , respectively $\mathrm{p} \leq 0.05)$, the best results found in talbinah 2 group.

Iron levels filled in normal range $(40-175 \mu \mathrm{L} / \mathrm{dL})$ of control group recorded non-significant increase $(0.254 \mathrm{p} \leq 0.05)$. The best results of talbinah groups found in talbinah 2 group high significant 


\section{Ola Ibrahim El-Desoky Ali}

values $(0.000 p \leq 0.05)$ between after and before experiment period followed by talbinah 1 group $(0.03$ $\mathrm{p} \leq 0.05$ ).Ferritin data of control group found in normal range (12 to $150 \mathrm{ng} / \mathrm{mL}$ for females) and illustrated non-significant increase $(0.245 p \leq 0.05)$. All talbinah groups recorded high significant values between after and before experiment period $(0.06$ and 0.000 , respectively $p \leq 0.05)$, the best results found in talbinah 2 group. Total iron binding capacity (TIBC) were in normal range $(285-510 \mu \mathrm{L} / \mathrm{dL})$, the control group demonstrated non-significant increase $(0.157 \mathrm{p} \leq 0.05)$. Talbinah 2 recorded high significant values between after and before experiment period $(0.000 p \leq 0.05)$ as the best results, followed by talbinah 1 group $(0.07 \mathrm{p} \leq 0.05)$.

Table (5)

Iron status as indicated by anemia and effect of Talbinah doses on girls

\begin{tabular}{|c|c|c|c|c|c|c|c|c|c|}
\hline \multicolumn{2}{|l|}{ groups } & $\begin{array}{c}\text { Hemoglobin } \\
(\mathrm{mg} / \mathrm{dL})\end{array}$ & Sig. & $\begin{array}{c}\text { Iron } \\
(\mu \mathrm{g} / \mathrm{dL})\end{array}$ & Sig. & $\begin{array}{c}\text { Ferritin } \\
\mathrm{ng} / \mathrm{mL}\end{array}$ & Sig. & $\begin{array}{l}(\mathrm{TIBC}) \\
(\mu \mathrm{g} / \mathrm{dL})\end{array}$ & Sig. \\
\hline \multirow[t]{2}{*}{ Pair 1} & $\begin{array}{l}\text { Control } \\
\text { before }\end{array}$ & $10.7 \pm 0.8$ & 0.783 & $150 \pm 0.4$ & 0.254 & $60 \pm 0.4$ & 0.245 & $280 \pm 0.3$ & 0.157 \\
\hline & $\begin{array}{c}\text { Control } \\
\text { after }\end{array}$ & $10.9 \pm 1.17$ & & $170 \pm 0.2$ & & $70 \pm 0.8$ & & $295 \pm 0.5$ & \\
\hline \multirow[t]{2}{*}{ Pair 2} & $\begin{array}{l}\text { Talbinah } \\
1 \text { before }\end{array}$ & $10.2 \pm .14$ & 0.021 & $133 \pm 0.3$ & 0.03 & $75 \pm 0.2$ & 0.06 & $270 \pm 0.9$ & 0.07 \\
\hline & $\begin{array}{c}\text { Talbinah } \\
1 \text { after }\end{array}$ & $11.5 \pm .48$ & & $165 \pm 0.6$ & & $100 \pm 0.3$ & & $330 \pm 0.8$ & \\
\hline \multirow[t]{2}{*}{ Pair 3} & $\begin{array}{l}\text { Talbinah } \\
2 \text { before }\end{array}$ & $10.5 \pm .40$ & 0.000 & $123 \pm 0.9$ & 0.000 & $80 \pm 0.4$ & 0.000 & $286 \pm 0.4$ & 0.000 \\
\hline & $\begin{array}{c}\text { Talbinah } \\
2 \text { after }\end{array}$ & $12.2 \pm .57$ & & $177 \pm 0.5$ & & $140 \pm 0.6$ & & $380 \pm 0.2$ & \\
\hline
\end{tabular}

Talbinah 1 (had one cup of Talbinah /day), Talbinah 2 (had two cups of Talbinah /day) Mean \pm Std. Deviation- Sig. at p $\leq 0.05$ (2tailed)

The intestine absorbs iron to balance the loss of iron due to menstruation. Uptake iron from the diet is also necessary to replace the small amount of iron normally lost daily via the breakdown of intestinal mucosal cells. Our data are synergic with the fact said non-heme iron absorption is increased by ascorbic acid, protein in the diet, and a low gastric $\mathrm{pH}$ that promotes more efficient food digestion. So, the use of buffalo milk was chosen. Ferritin is released into the blood stream; plasma (or serum) ferritin concentrations typically reflect iron stores. So, our results confirmed iron level by estimating ferritin levels. A total iron binding capacity (TIBC) test is a type of blood test that gauges whether there's too much or too little iron in the blood stream (William et al., 2014). For this reason, the iron, ferritin and TIBC tests were evaluated to detect symptoms of anemia, or iron deficiency in the blood.

Results in table (6) illustrated comparison of zinc parameters after and before experiment compared with the normal values. Control group recorded non-significant increase $(0.257 p \leq 0.05)$. Talbinah 2 group showed high significant between after and before $(0.000 p \leq 0.05)$, followed by talbinah 1 group as significant values $(0.015 p \leq 0.05)$.

Albumin levels was compared with the normal values in all groups (table 6 ). The control group showed non-significant increase $(0.234 \mathrm{p} \leq 0.05)$. The best results found in talbinah 2 group which recorded high significant difference between after and before $(0.000 p \leq 0.05)$, followed by talbinah 1 group as significant values $(0.02 p \leq 0.05)$. 
Egypt. J. of Nutrition and Health Vol. 15 No. 1 January (2020)

Table (6)

Zinc and albumin parameters of control and treated groups as after and before experiment

\begin{tabular}{c|c|c|c|c|c}
\hline \multicolumn{2}{c|}{ Groups } & Zinc $\mu \mathrm{g} / \mathrm{dL}$ & Sig. & Albumin g/dL & Sig. \\
\hline \multirow{2}{*}{ Pair 1 } & Control before & $144.42 \pm 7.26$ & 0.257 & $3.3 \pm .12$ & 0.234 \\
\cline { 2 - 6 } & Control after & $152.75 \pm 7.93$ & & $3.5 \pm .23$ & \\
\hline \multirow{2}{*}{ Pair 2 } & Talbinah 1 before & $147.20 \pm 9.68$ & 0.015 & $3.1 \pm .11$ & 0.02 \\
\cline { 2 - 6 } & Talbinah 1 after & $156.67 \pm 8.71$ & & $4.4 \pm .22$ & 0.000 \\
\hline \multirow{2}{*}{ Pair 3 } & Talbinah 2 before & $146.18 \pm 19.40$ & 0.000 & $2.9 \pm .31$ & $5.0 \pm .36$ \\
\cline { 2 - 6 } & Talbinah 2 after & $160.42 \pm 17.18$ & & &
\end{tabular}

Talbinah 1 (had one cup of Talbinah /day), Talbinah 2 (had two cups of Talbinah /day) Mean \pm Std. Deviation- Sig. at p $\leq 0.05$ (2-tailed)

Serum zinc concentration is used to evaluate the zinc status of populations. Nutritionally, Zinc is an essential trace mineral required for enzymes and a coenzyme for $>300$ metalloproteins, in the regulation of gene expression for thousands of genes and as a structural component for $\sim 2500$ transcription factors (Wood., 2000). In humans, mild or moderate zinc deficiency may lead to growth retardation and delayed puberty in adolescents, hypogonadism in males, dermatitis, reduced appetite, mental lethargy, and delayed wound healing (Prasad., 1985).

Albumin is one of the most abundant proteins found in the blood. The liver releases albumin as part of its normal functioning. Historically, serum proteins such as albumin have been widely used by physicians to determine patient nutritional status, because it is a more strong indicator of acute changes in a nutritional status (Shishira et al., 2016). And when it was mentioned from these studies and facts, we had to compare the level of albumin as a strong indication of the protein status in the body before and after the experiment to confirm the effective role of daily consumption of talbinah under study.

\section{Conclusion}

The research was carried to know the nutritional effect of daily talbinah intake for girls. The results proved that talbinah can improve nutritional status of girls after daily intake for three months, because of its high nutritional value especially in minerals, vitamins and proteins. Hence, the study recommends the importance of taking talbinah to maintain health and nutritional status in the different stages of development, especially in the reproductive stage of girls. 


\section{References}

A.O.A.C. (1997).

Official Methods of Analysis, 16 Ed. Association of Official Analytical Chemists. Virginia, USA: Arlington.

A.O.C.S. (1994).

Official Methods of the American Oil Chemists Society. Illinois, U.S.A.: Arlington.

Abd El-Rahman ZEDF (2001).

Fatah El-bary fe sharh saheeh El-buhkary. EL-damam. Saudi Arabia: Ibn El-Goze.

Abd Rabo Marwa M, Wahman Lobna F and Yousef Magda HM (2018).

Potential Impact of Talbina on Pituitary-Adrenal-Gonadal Disorders in Hypothyroid Adult Female Rats. Scholars Research Library Der Pharmacia Lettre, 10 [3]: 91-102.

Abdel-Hassib, R. (2007).

Talbina : A food and drug. Mecca, K.S.A.: International organization of the holey quran and hadith.

Badrasawi Manal, Shahar Suzana, Abd Manaf Zahara and Haron Hasnah, (2013).

Effect of Talbinah food consumption on depressive symptoms among elderly individuals in long term care facilities, randomized clinical trial. Clinical Interventions in Aging 8, 279-285.

Bassem Y. Sheikh (2016).

The role of prophetic medicine in the management of diabetes mellitus: A review of literature. Journal of Taibah University Medical Sciences, 11(4), 339e352.

Bates HM. (1980).

How to Detect Iron Deficiency Before Anemia Develops. Laboratory Pathfinder 1:17-22.

Bawazir A.E. (2010).

Investigations on the chronic effect of talbina (barley water) on hormone (Cortisol and Testosterone), reproductive system and some neurotransmitter contents in different brain areas of male albino rats. American-Eurasian Journal of Scientific Research 5 (2): 134-142.

Betk K., and Savelsberg, W. (1950).

Stufenphotometeris cyanhomoglobin. Biochem. Zeitchr., 320: 431.

\section{Centers for Disease Control and Prevention (2009a).}

(CDCP). Adult BMI Retrieved August 10 2009, from http://www. cdc.gov /healthy weight/ assessing/ bmi/ adult bmi /index.html.

\section{Chapman HD and Pratt PF (1961).}

Methods of Analysis for Soils, Plants and Waters,Univ.of California ,Div.Agric.Sc. 


\section{Egypt. J. of Nutrition and Health Vol. 15 No. 1 January (2020)}

Cho, Susan, Lu, Q., Fahey, G.C. and Klurfeld, D. M. (2013).

Consumption of cereal fiber, mixtures of whole grains and bran, and whole grains and risk reduction in type 2diabetes, obesity, and cardiovascular disease. Am. J. Clin. Nutr. 98: 594619.

Dietary Reference Intakes (DRIs) (1997).

Estimated Average Requirements. Food and Nutrition Board, Institute of Medicine, National Academies. 2011. These reports may be accessed via www.nap.edu.

Elagamy E.I. (2000).

Effect of heat treatment on camel milk proteins with respect to antimicrobial factors: a comparison with cows' and buffalo milk proteins. Food Chemistry. Volume 68, Issue 2, February, Pages 227-232.

Food and A griculture Organization of the United Nations Rome (2018).

Dietary Assessment, A resource guide to method selection and application in low resource settings.

Forman DT and Parker SL. (1980).

The measurement and interpretation of Serum Ferritin. Ann Clin Lab Sci. 10:345-50.

Hashemi, J.M. (2015).

Biomedical Effects of Barley-A Review. New York Science Journal, 8(3): 52-55.

Hosseinzadeh, S., Jafarikukhdan, A., Hosseini, A. and Armand, R. (2015).

The Application of Medicinal Plants in Traditional and Modern Medicine: A Review of Thymus vulgaris. International Journal of Clinical Medicine, 6, 635-642.

Jackson ML (1973).

Soil Chemical Analysis. Prentice Hall of India Private Limited, New Delhi.

Kalton, C. (1967).

Introduction to Statistical From Sociatomssientistis. 2nd Ed. Acd. Press, London.

Kamal M.E. Youssef, Fawzy Abd El-Kader El-Fishawy, El-Sayed Abd El-Naby Ramadan and Asmaa MohamedAbd El-Rahman (2013).

Nutritional Assessment of Barley, Talbina and Their Germinated Products. Frontiers in Science, 3(2): 56-65. DOI: 10.5923/j.fs.20130302.02.

Khalaf G. and Mohamed A-G. (2008).

Effect of Barley (Hordeum Vulgare) on the liver of diabetic rats: histological and biochemical study. Egypt J Histol; 31: 245e255.

Khedkar, C.D. and Deosarkar, S.S. (2016).

Buffalo Milk in Encyclopedia of Food and Health. 


\section{Ola Ibrahim El-Desoky Ali}

\section{Kirgbright GF (1980).}

Atomic absorption spectroscopy, Elemental analysis of biological materials. Vienna Technical Report Series. Int Atomic Agency. 197: 141-165.

Krause JR, and Stolc V. (1979).

Serum Ferritin and Bone Marrow Iron Stores, 1. Correlation with Absence of Iron in Biopsy Specimens. Am J Clin Pathol;72:817-20.

Kumari, R. and Kotecha, M. (2015).

Physicochemical and nutritional evaluation of Yava (Hordeumvulgare Linn.). International Research Journal of Pharmacy, 6(1): 70-72.

Lahouar Lamia, Ghrairib Fatma, El Arema Amira, Medimaghc Sana, El Felahc Mouledi, Ben Salemd Hichem and Achoura Lotfi (2017).

Biochemical composition and nutritional evaluation of barley rihane (Hordeum vulgare I.) Lahouar., Afr J Tradit Complement Altern Med14(1):310-317.

Livesy G (1995).

Metabolizable energy of macro-nutrients. Am J of Clin Nutr 62, 11355-11425.

National Nutrition Institute (NNI) (2006).

Food Composition Tables for Egypt. 2nd Edition, Cairo.

Park K. and Park, S. (2010).

Textbook of Preventive and Social Medicine, 20th ed. Banarsidas Bhanot publishers Jabalpur, p:347.

Pellet PL and Sossy S (1970).

Food composition tables for use in the Middle East. Beirut-lebanon: American University of Beirut.

Prasad AS.(1985).

Clinical, endocrinological and biochemical effects of zinc deficiency. Clin Endocrinol Metab;14(3):567-89.

Sarfraz Ahmad (2013).

Buffalo Milk. Wiley Online Library. Chapter 24 https:// doi.org/ 10.1002/ 9781118534168. ch24.

Shishira Bharadwaj, Shaiva Ginoya, Parul Tandon, Tushar D. Gohel, John Guirguis, Hiren Vallabh, Andrea Jevenn and Ibrahim Hanouneh (2016).

Malnutrition: laboratory markers vs nutritional Assessment. Gastroenterology Report, 4(4), 272-280. doi: 10.1093/gastro/gow013.

Van Assendelft OW, Fairbanks VF, Gunter EW and Turner WE. (1995).

Proposed standard for the determination of serum iron and total iron-binding capacity. Provisional Standard, National Committee for Clinical Laboratory Standards. 


\section{Egypt. J. of Nutrition and Health Vol. 15 No. 1 January (2020)}

Wardley, B.L., J.W.L. Pontis, and L.S. Taitz, (1997). Handbook of child nutrition. $2^{\text {nd }}$ ed. Oxford University press, Oxford. P. 54-72

William E. Winter, Lindsay A. L. Bazydlo and Neil S. Harris (2014).

The Molecular Biology of Human Iron Metabolism. Lab Med Spring;45:92-102. DOI: 10.1309/ LMF28S2 GIMXNWHMM.

Wood RJ. (2000).

Assessment of marginal zinc status in humans. J Nutr;130(5 Suppl):1350S-4S.

World Health Organization WHO (2004).

Body Mass Index Classification: WHO Bulletin.

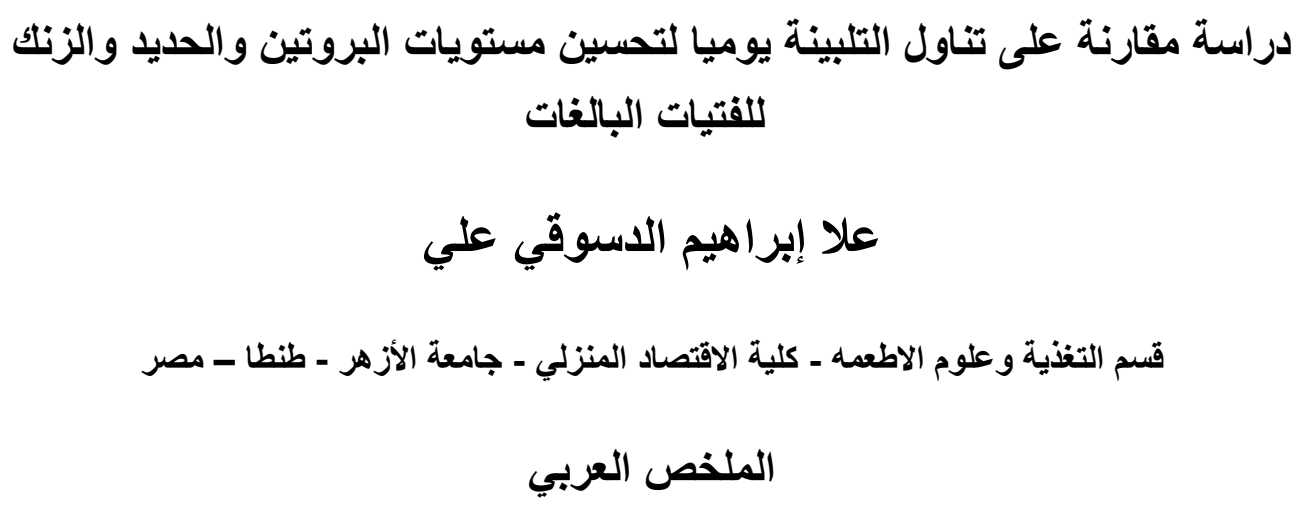

تهدف الدراسة إلى تأكيد دور التلبينة لضبط مستوى البروتين والمعادن كمشكلة غذائية للفتاة البالغة. وقد تم اجراء

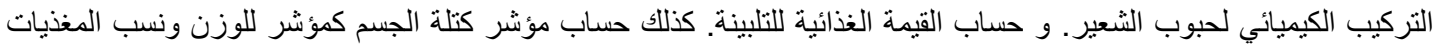

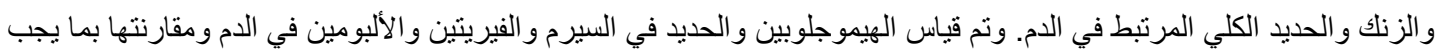

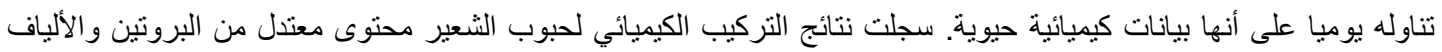

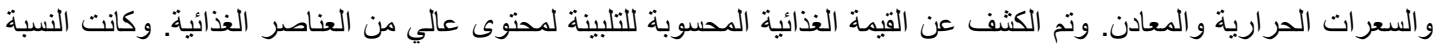

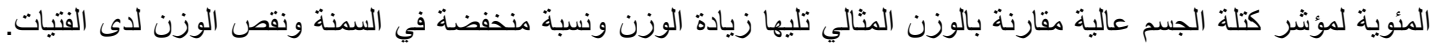

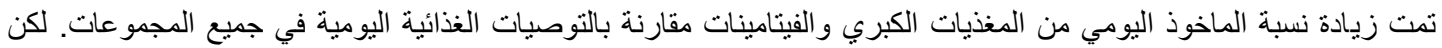

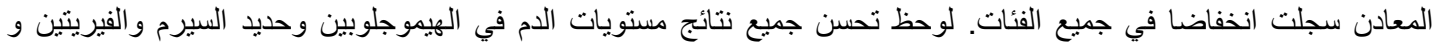
الحديد الكلي المرتبط والزنك والألبيومين عن طريق تتناول الفنيات 2 كوب ثم 1 كوب من التلبينة. لذا فإن هذه النتائج تثجع استخدامات التلبينة لتحسين الحالة التغذوية للفنيات البالغات. الكلمات المفتاحية: الثعبر ، الحليب ، الهيموجلوبين ، الحديد ، الفيريتين ، الحديد الكلي المرتبط في الدم. 